\title{
Proxy Information Seeking by Users of a Parenting Information Website: Quantitative Observational Study
}

Reem El Sherif, MBChB, MSc; Pierre Pluye, MD, PhD; Tibor Schuster, PhD; Roland Grad, MD, MSc

Department of Family Medicine, McGill University, Montreal, QC, Canada

Corresponding Author:

Reem El Sherif, MBChB, MSc

Department of Family Medicine

McGill University

5858 Ch. de la Côte-des-Neiges, Suite 300

Montreal, QC, H3S 1Z1

Canada

Phone: 15143987375

Email: reem.elsherif@mail.mcgill.ca

\section{Abstract}

Background: One of the largest groups of consumers who seek health information on the internet are parents of young children, as well as people in their social circle. The concept of proxy seeking (on behalf of others) has been explored in the literature, yet little is known about the outcomes.

Objective: The main aim of this study was to describe consumer health information outcomes reported by proxy seekers using a parenting website.

Methods: We conducted a 2-year quantitative observational study. Participants were parents of 0- to 8-year-old children and members of their entourage in Canada who had accessed Naître et Grandir through the website or through a weekly newsletter. For each Naître et Grandir webpage, participants' perceptions regarding the outcomes of seeking and using specific webpages were gathered using a content-validated Information Assessment Method questionnaire. We compared the outcomes reported by parents with those reported by members of their entourage after consulting a parenting information website and explored if the method of accessing the information by the proxy seekers (website or weekly newsletter) changed the outcomes reported. For key primary survey items, the chi-square test was conducted, and differences in relative frequencies of responses were computed along with confidence intervals.

Results: A total of 51,325 completed questionnaires were included in the analysis, pertaining to 1079 Naître et Grandir webpages (mean 48; range 1-637). Compared to parents, individuals in the entourage are more likely to report using the information in discussion with others (mean difference 0.166 , 95\% CI 0.155-0.176). Parents, on the other hand, were more likely than the entourage to report using the information to better understand (mean difference $0.084,95 \%$ CI $0.073-0.094$ ), to decide to do something (mean difference $0.156,95 \%$ CI 0.146-0.166), or to do something in a different manner (mean difference $0.052,95 \%$ CI 0.042-0.061). In addition, results suggest that the differences in perceived benefits of parenting information by the entourage depend on how they access the information. Respondents who were actively seeking the information (through the website) were more likely to report that the information would help them be less worried (mean difference 0.047; 95\% CI 0.024-0.069), handle a problem (mean difference $0.083 ; 95 \%$ CI $0.062-0.104$ ), and decide what to do with someone else (mean difference $0.040,95 \%$ CI 0.020-0.058). Respondents who passively acquired the information (through the newsletter) were more likely to report that the information would help improve the health or well-being of a child (mean difference 0.090; 95\% CI 0.067-0.112).

Conclusions: By better understanding how consumers and their entourages use information, information providers can adapt information to meet both individual and group needs, and health care practitioners can target patients' entourages with web-based health information resources for dissemination and use.

(JMIR Pediatr Parent 2022;5(1):e32406) doi: 10.2196/32406

\section{KEYWORDS}

consumer health information; information seeking behavior; child development; child health; information outcomes; health information; digital health; parenting; online information 


\section{Introduction}

\section{Background}

In 2017, almost all (99.0\%) Canadian households had fixed broadband internet access [1], and $75 \%$ to $96 \%$ of Canadians aged 15 to 64 years used the internet on a daily basis [2]. This is in line with other Organization for Economic Cooperation and Development (OECD) countries, in which more than $80 \%$ of households have access to high-speed internet [3]. In these countries, the proportion of adults seeking consumer health information on the internet has more than doubled between 2008 and 2017 [4]. The internet is a frequently accessed platform for finding consumer health information, in addition to common health information sources such as health care professionals or members of one's social circle, and other sources such as books and television [5,6]. The use of trustworthy consumer health information from the internet can improve quality of life and is generally associated with increased empowerment of consumers and their families and with improved health outcomes [6-8].

There are, however, still barriers to benefitting from consumer health information from the internet. These include illness challenges, such as someone being too physically or mentally incapacitated to start a search for themselves. A second barrier may be lower eHealth literacy, meaning a consumer's ability to seek, find, understand, and appraise consumer health information from the internet and apply the knowledge gained to addressing health issues. At least one-third of the population of 18 OECD countries may have low health literacy [9]. Moreover, when faced with a stressful situation, consumers may experience transitory low literacy level, as the interdependence between information and emotion is well established in the literature [10]. Finally, there are negative outcomes (or tensions) reported by users seeking consumer health information from the internet and health care practitioners.

Our recent qualitative study [11] described personal tensions, such as increased anxiety and interpersonal tensions between patients and physicians as a result of discussing consumer health information from the internet, and service-related tensions, such as postponing a clinical visit [11]. One strategy to reduce these tensions is discussing the information with someone in one's social circle [11]. Approximately $90 \%$ of individuals in OECD countries report having access to social support (eg, relatives or friends) who can help them in times of need [12]. Access to social support is positively linked to internet access and use because these providers of support are internet users themselves and have relevant support and awareness [13]. Proxy consumer health information seeking on the internet is a common phenomenon: almost two-thirds of consumer health information seekers have reported searching on behalf of someone else to provide informational social support [14-16]. This proxy consumer health information seeking on the internet may overcome previously mentioned barriers. This is especially true if the support provider has higher eHealth literacy than the receiver: they are thus better able to explain, contextualize, or validate the information $[17,18]$. However, while there are several studies [19-21] that explored behavior related to proxy consumer health information seeking on the internet, few explored how the seeker uses the information with others, and what outcomes they report as a result of this use.

\section{Parents and Proxy Health Information-Seeking Behavior and Outcomes}

One of the largest groups of consumers of web health information consumers is parents of young children. A recent systematic review [22] and empirical studies [23,24] on how parents find, use, and evaluate consumer health information from the internet for their children reported that parents worldwide are heavy users across diverse circumstances. Parents find the information themselves or reach out to their social circle (or entourage) for tailored advice, emotional support, and culturally relevant parenting information [25]. A 2015 survey, conducted in Quebec, of a representative sample of 23,693 parents of preschool children showed that only $1.5 \%$ of parents do not know where to find information on the internet about children, either directly or mediated by someone else [26] as a proxy- "seeking information in a nonprofessional or informal capacity on behalf (or because) of others without necessarily being asked to do so [27]."

Previous work [28] shows that the use of high-quality parenting consumer health information from the internet by mothers can lead to benefits such as decreased worries and increased self-confidence in decision-making, regardless of socioeconomic status [28]. However, little is known about proxy information seeking by the entourage of parents. The main objective of this study was to explore these outcomes as reported by users of a parenting information website. A secondary objective was to explore if the method of obtaining the information influences the reported outcomes of proxy information seeking on the internet.

\section{Methods}

\section{Design}

We conducted a 2-year quantitative observational study. Ethical approval was obtained from the institutional review board of the Faculty of Medicine, McGill University, prior to the start of data collection. We used the STROBE (Strengthening the Reporting of Observational Studies in Epidemiology) checklist [29].

\section{Consumer Health Information From the Internet Outcomes}

A conceptual framework (Figure 1) was adapted from [30]. There are 4 types of influencing factors: individual characteristics (eg, age and income), sociotechnical factors (eg, eHealth literacy and social support), patient-professional relationships, and education-health-social resources. Together, these factors determine the extent to which information is accessed and how it is used by patients. An information need is a condition in which "certain information contributes to the achievement of a genuine or legitimate information purpose [31]." These needs may be explicitly stated or implicitly understood based on an individual's health status or situation [31]. Seeking consumer health information on the internet is 
purposive and active searching for information as a consequence of an information need or to satisfy a goal [32]. Finally, there are 4 individual levels of web-based consumer health information-seeking outcomes: situational relevance, cognitive impact, and use of information, and health and health care-related outcomes.

Figure 1. Outcomes framework.

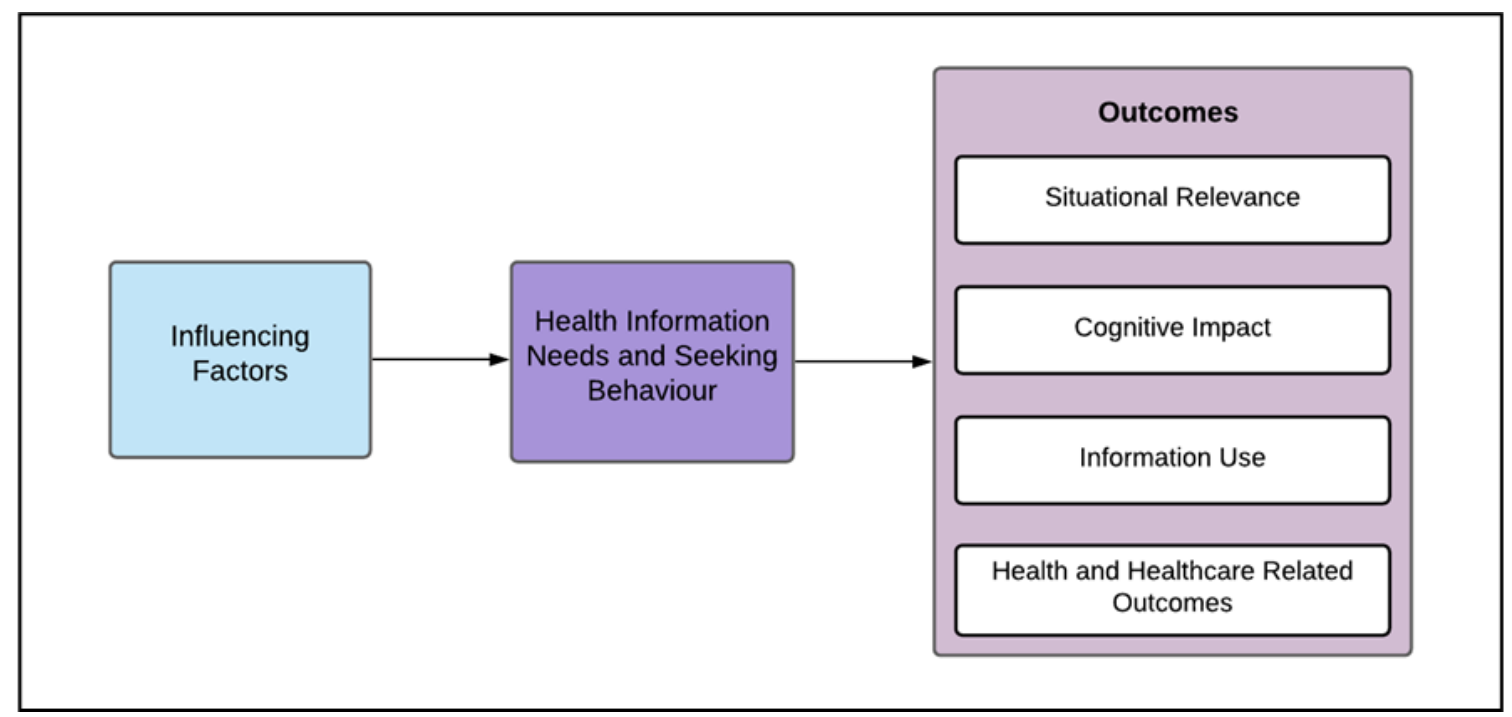

\section{Naître et Grandir}

The Naître et Grandir website provides parents with support in raising their children, from the time they are conceived until they are 8 years old.

Naître et Grandir is funded by the Lucie and André Chagnon Foundation, a philanthropic organization that seeks to contribute to the prevention of poverty through the creation of conditions and environments that are favorable to the educational success of children, specifically, those from socially vulnerable families and communities. Low health literacy levels in parents are detrimental to child health education, healthy behaviors, health, and medication, thus Naître et Grandir is an important resource for French-speaking parents and their entourage [33]. In addition to accessing the website directly, Naître et Grandir readers can sign up to receive a weekly newsletter containing links to Naître et Grandir webpages tailored to their child's age. Naître et Grandir provides free parenting information content produced using an expert-based process and an editorial process that caters to lower health literacy levels (Grade 8 reading levels) with additional audio and video formats [28].

Since 2014, our team at McGill University and Naître et Grandir have worked in partnership to implement the Information Assessment Method questionnaire for evaluating the pages of parenting information. In addition, Naître et Grandir has been able to improve informational content based on the comments provided by Information Assessment Method users, which are coded by 2 editors in a web-based system. This is referred to as 2-way knowledge translation [34].

\section{Information Assessment Method}

The framework is operationalized in the Information Assessment Method questionnaire used to evaluate health information outcomes from the viewpoint of information users (clinicians, managers, patients and public) [35]. The Information Assessment Method questionnaire has been content validated for different audiences using participatory mixed methods (integrating quantitative survey data with qualitative insights [36]). It has been implemented by different information providers to allow information users to rate specific health information content on the internet (eg, a webpage), stimulate their reflection, and collect feedback [35]. Consequently, responses and comments can be used by information providers to improve content.

The validity of the Information Assessment Method has been assessed on 2 occasions: It was first validated specifically for parents in 2015 using quantitative data (raters' responses) and qualitative data (raters' comments and qualitative interviews [37]. It was then validated again in 2019 specifically for parents of lower socioeconomic status using qualitative data from interviews with low-socioeconomic status parents used in this study [28] and was validated in French (as it is implemented with Naître et Grandir) and underwent a transcultural adaptation into English (Multimedia Appendix 1). When Naître et Grandir readers land on a webpage corresponding to a specific topic (directly or through the newsletter link), a lateral tab appears inviting them to complete a survey (Figure 2). 
Figure 2. Screenshot from a Naître et Grandir page.

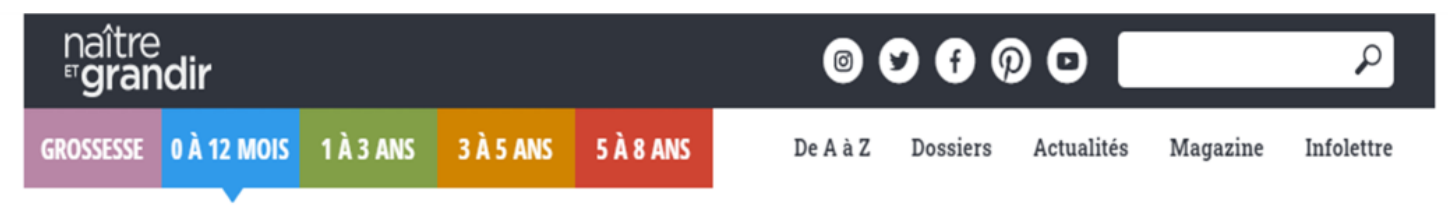

\begin{tabular}{|c|c|c|}
\hline Développement & \multicolumn{2}{|c|}{ Accueil/ / 0 a 12 mois / Développement / 1 mois / } \\
\hline \multicolumn{3}{|l|}{ Nouveau-né } \\
\hline \multicolumn{3}{|l|}{1 mois } \\
\hline 2 mois & AFFECTIF & MOTRICITÉ FINE \\
\hline \multicolumn{3}{|l|}{3 mois } \\
\hline \multicolumn{3}{|l|}{4 mois } \\
\hline \multicolumn{3}{|l|}{5 mois } \\
\hline \multicolumn{3}{|l|}{6 mois } \\
\hline 7 à 9 mois & \multirow{4}{*}{\multicolumn{2}{|c|}{$\begin{array}{l}\text { Le développement de la motricité fine } \\
\text { signifie que l'enfant apprend à utiliser } \\
\text { certains petits muscles des doigts et des } \\
\text { mains pour faire des mouvements précis } \\
\text { afin d'atteindre, d'agripper et de manipuler } \\
\text { de petits objets. Les nouveau-nés maîtrisent } \\
\text { très peu leur motricité fine, mais votre bébé } \\
\text { aporendra. au cours des prochains mois. à }\end{array}$}} \\
\hline 10 à 12 mois & & \\
\hline Nourrir & & \\
\hline Soins et bien-être & & \\
\hline
\end{tabular}

\section{Study Participants and Data Collection}

Data collection was co-constructed with Naître et Grandir in the course of the ongoing partnership. The editors of Naitre et Grandir provided feedback on the questionnaire; however, they did not influence the data analysis and interpretation.

Participants in this study were Naître et Grandir readers in Canada and 4 other OECD countries with francophone populations (France, Belgium, Switzerland, and Luxembourg) that have similar health and social systems and comparable average household incomes, internet access, and reported social support levels [12].

Each participant had arrived at a specific Naître et Grandir webpage (either directly through the website), had clicked on the lateral tab, and had completed the Information Assessment Method questionnaire asking them to evaluate that specific Naître et Grandir webpage during the study period (April 13, 2019 to March 30, 2021). All completed questionnaires were included in the analysis. Among them, participants were divided into 2 group - self-identified parents of 0 - to 8-year-old children or an entourage member (grandparent, family member, friend, neighbor, or professional working with children). A second analysis was conducted in the entourage group between those who had accessed the Naître et Grandir webpage and Information Assessment Method questionnaire through the weekly newsletter and those who had landed directly on the Naître et Grandir website. Variables included in the analysis correspond to the Information Assessment Method questions. No incentive was provided to participate.
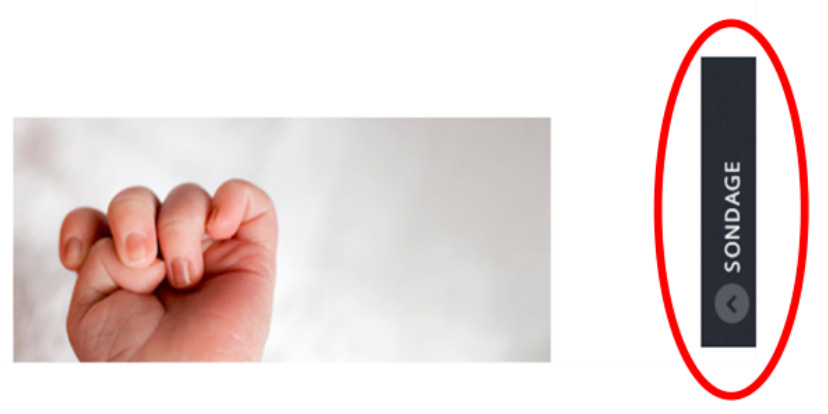

\section{Statistical Analysis}

Comparisons (1) between parents and entourage Information Assessment Method responses and (2) between newsletter and website Information Assessment Method responses from entourage were assessed using frequency analyses. Difference in proportions with $95 \%$ confidence intervals were calculated $[38,39]$. To take multiple comparisons into account and retain a global Type I error level of 5\%, confidence levels were corrected using Bonferroni adjustment. In addition, the Pearson chi-square test was used to determine whether the differences between 2 groups of participants were statistically significant. Test results were deemed statistically significant when $P$ values $<.001$. All statistical analyses were completed using SAS software (version 9.4; SAS Institute).

\section{Hypotheses}

Based on our previous work exploring information outcomes, we hypothesized that, when the information is considered relevant and easy to understand, the entourage would be more likely to report discussing the information with others. We also hypothesized that, similar to previous work on parents' responses, there would be a difference in entourage responses based on mode of access.

\section{Results}

\section{All Respondents}

Over the 2-year study period, 69,260 Information Assessment Method questionnaires were completed. Questionnaires completed by participants outside the countries of interest in this study and by participants who did not identify as parents or entourage members were excluded (Figure 3). In total, 51,325 
completed Information Assessment Method questionnaires were included in the analysis, pertaining to 1079 Naître et Grandir webpages (mean 48; range 1-637). Most respondents were in Canada $(29,972 / 51,325,58.4 \%)$ and France $(18,461 / 51,325$, $36 \%$ ) (Figure 4). Parents comprised 79.2\% (40,628/51,325) of

Figure 3. Information Assessment Method (IAM) questionnaires included in the analysis.

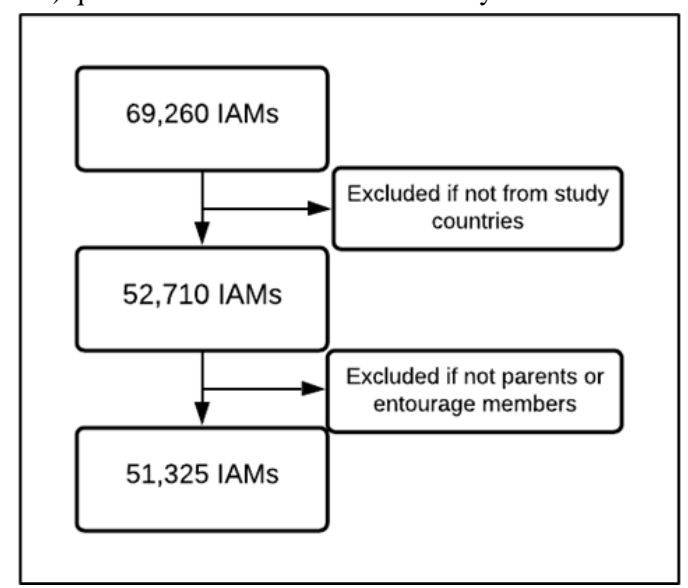

Figure 4. Respondent distribution by country.

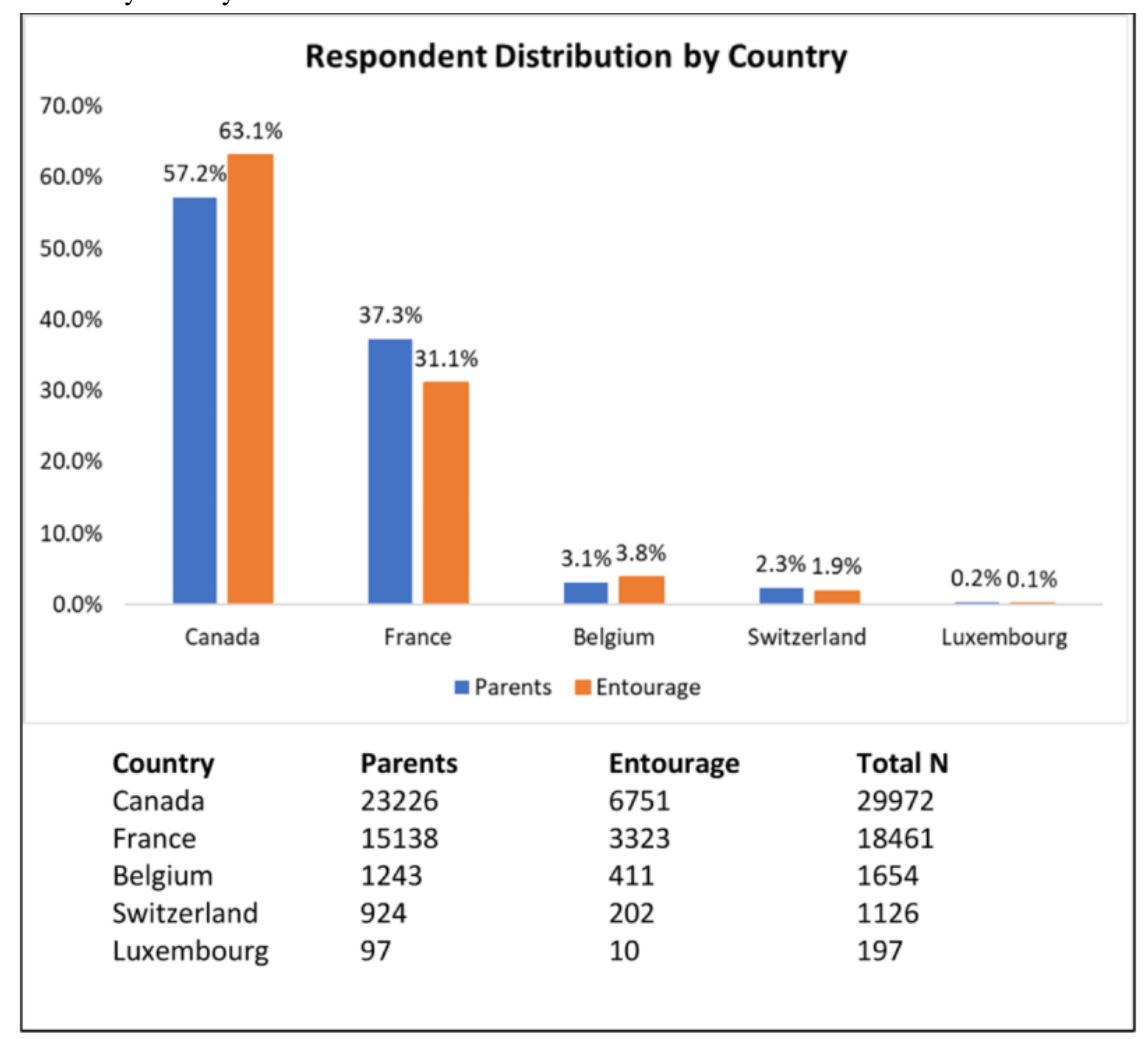

participants, and grandparents were the most common entourage members $(6309 / 51,325,12.3 \%)$, followed by professionals, family, and friends $(4388 / 51,325,8.5 \%)$. The response rates of parents and entourage exhibited similar patterns (Figure 5). 
Figure 5. Response rate by month.

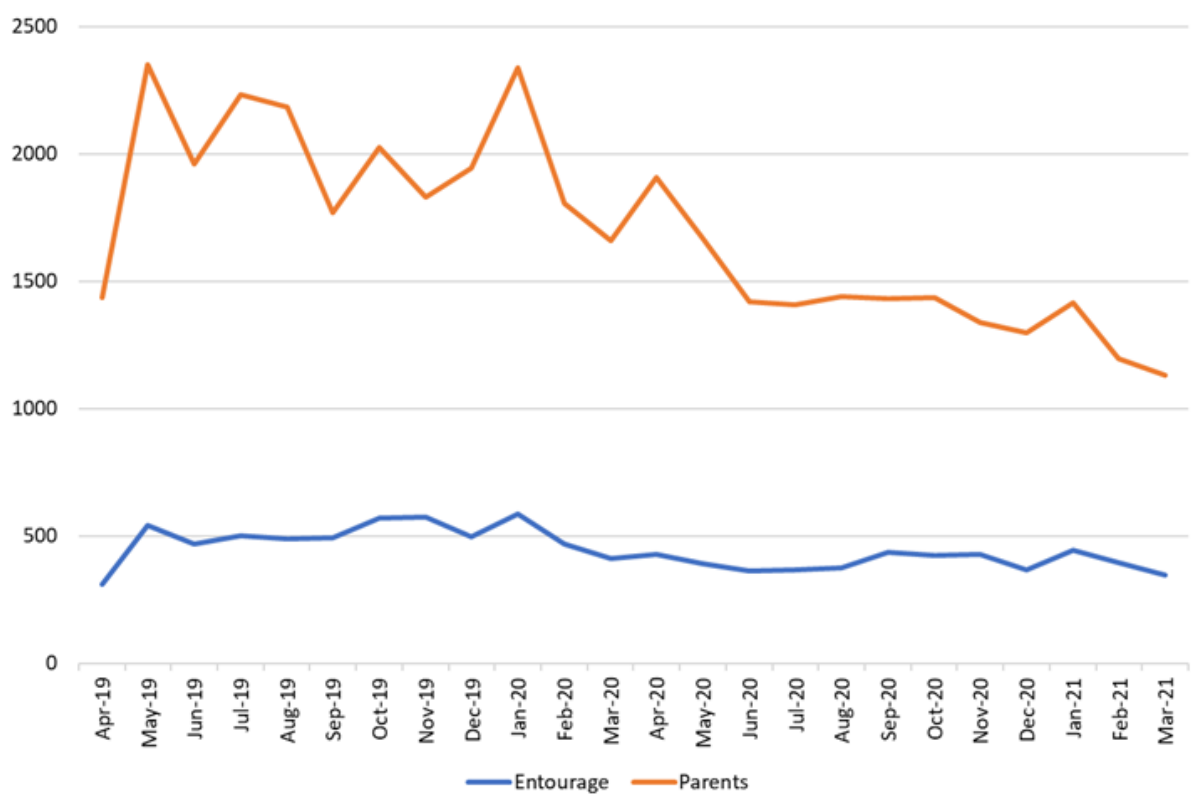

\section{Comparing Parents and Entourage}

Of the 51,325 Information Assessment Method questionnaires, $40,628(79.2 \%)$ were completed by parents and 10,697 (20.8\%) were completed by entourage members.

Parents were more likely to report using parenting information to better understand (mean difference 0.084 , 95\% CI 0.073-0.094), to decide to do something (mean difference 0.156, 95\% CI 0.146-0.166), or to do something in a different manner (mean difference $0.052,95 \%$ CI 0.042-0.061). They were also more likely to report that it helped them improve the health or well-being of a child (mean difference 0.039, 95\% CI $0.028-0.049$ ) and to be less worried (mean difference 0.104, 95\% CI 0.093-0.114). The entourage members were more likely to use the information in discussion with someone else (mean difference 0.166 , 95\% CI $0.155-0.176$ ) and report that the information helped them decide what to do with someone else (Table 1). 
Table 1. Perceived information outcomes: Information Assessment Method responses of entourage members and parents.

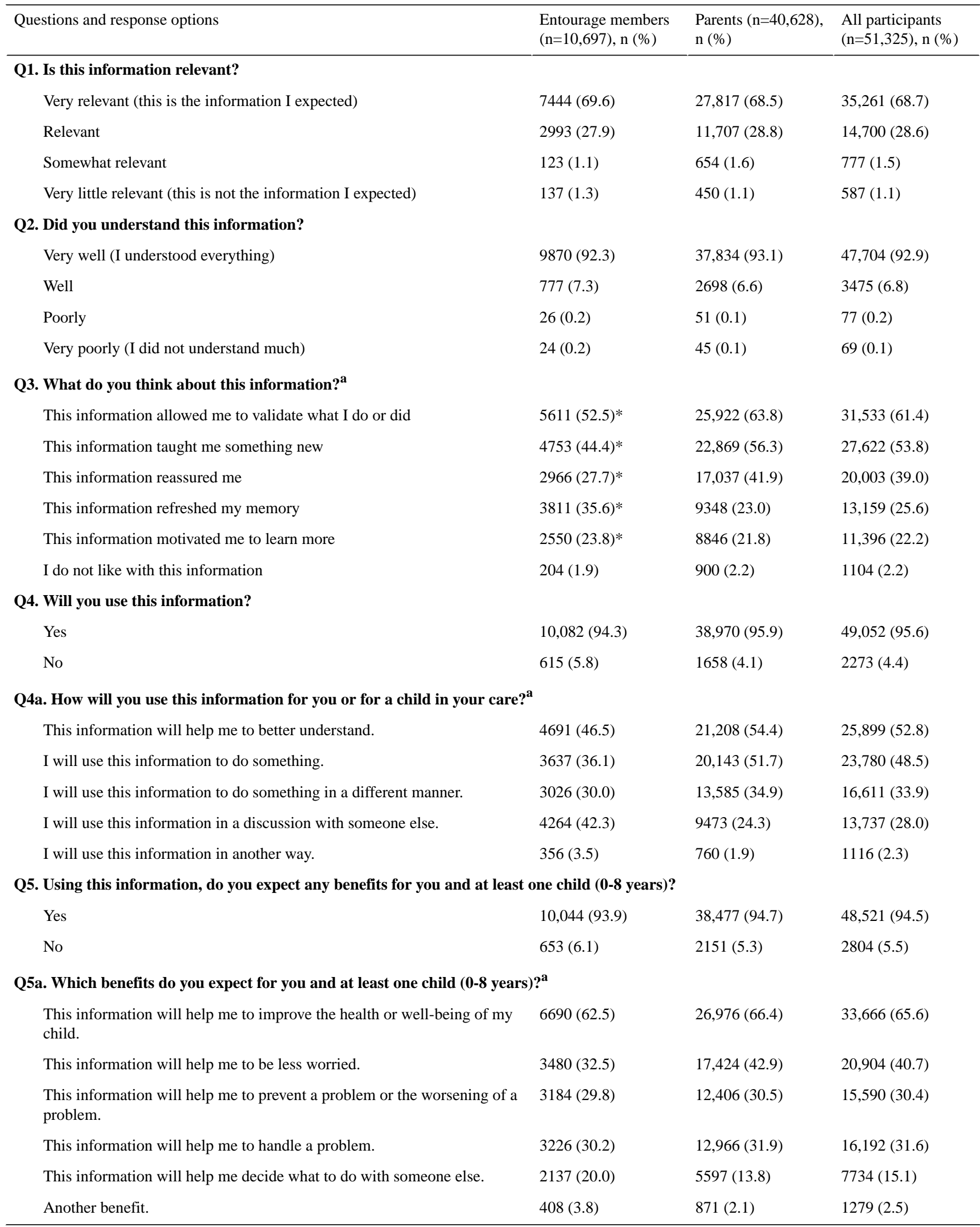

${ }^{\mathrm{a}}$ More than 1 option could be selected. 


\section{Comparing Website and Newsletter Respondents}

Of 10,697 Information Assessment Method questionnaires completed by the entourage, $1953(18.3 \%)$ accessed the webpage through the newsletter and $8744(81.7 \%)$ directly through the website. Respondents through the newsletter were more likely to report using the information to do something (mean difference $0.117,95 \%$ CI $0.092-0.141$ ) or do something differently (mean difference $0.067,95 \%$ CI $0.044-0.090$ ) and expected that the information would help to improve the health or well-being of a child (mean difference 0.090; 95\% CI 0.067-0.112). Respondents who accessed Naître et Grandir directly through the website were more likely to report that using the information would help them be less worried (mean difference $0.047 ; 95 \%$ CI 0.024-0.069), handle a problem (mean difference $0.083 ; 95 \%$ CI 0.062-0.104), and decide what to do with someone else (mean difference $0.040,95 \%$ CI 0.020-0.058). Both groups were equally likely to report using the information in discussion with someone else (mean difference 0.015 ; 95\% CI -0.009-0.040) (Table 2). 
Table 2. Perceived information outcomes: Information Assessment Method responses of entourage newsletter and website respondents.

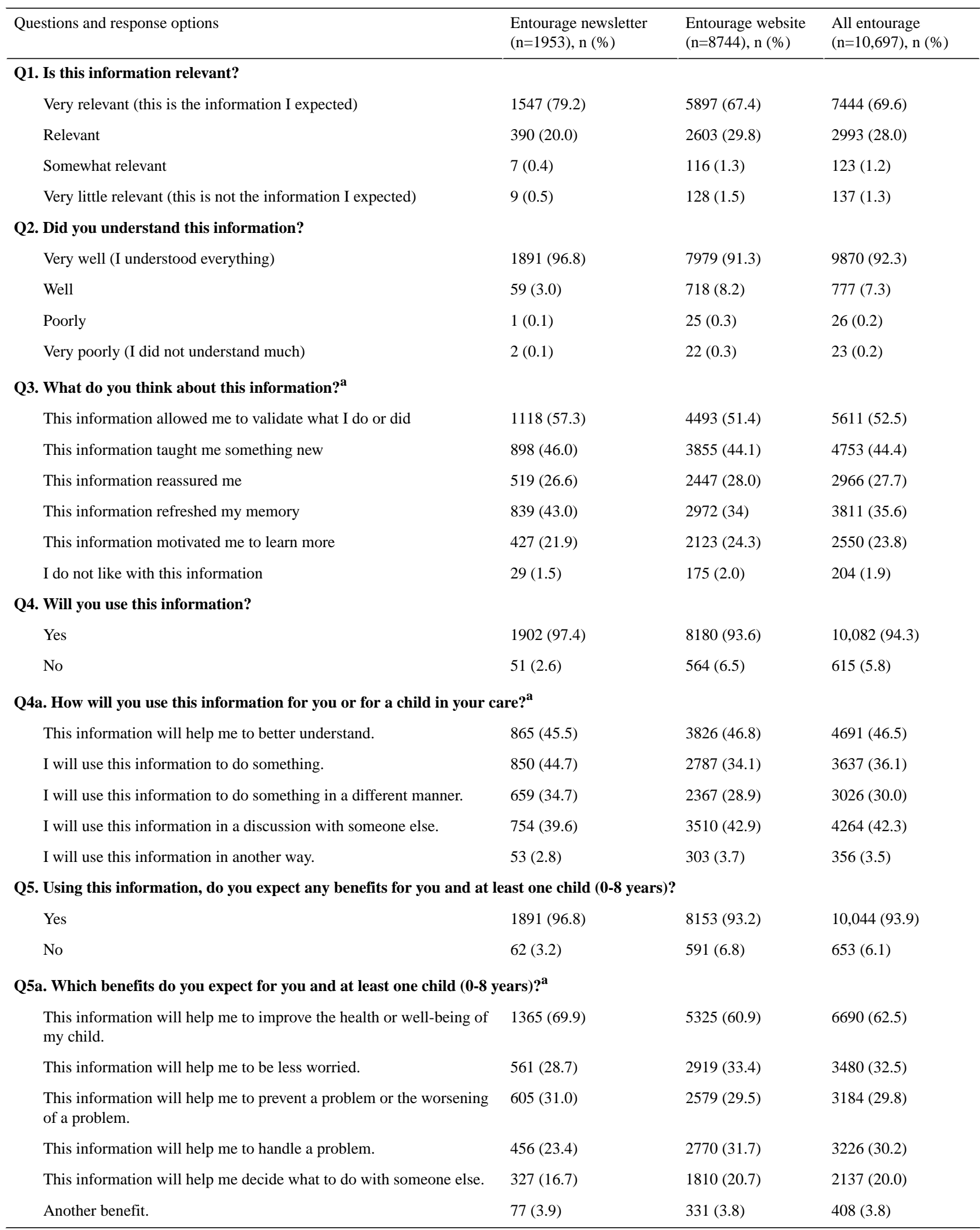

${ }^{\mathrm{a}}$ More than 1 option could be selected. 


\section{Discussion}

\section{Principal Findings}

Results support our first hypothesis that individuals in the entourage were more likely to report using the information in discussion with others. Parents, on the other hand, were more likely to report using the information to do something. This may reflect the trustworthiness of the information on Naitre et Grandir - the entourage felt comfortable sharing it and parents feel comfortable applying it.
Our second hypothesis was also supported. Results suggest that the differences in perceived outcomes reported by the entourage depend on how they access the information. When the information is acquired through active seeking by the respondents through the Naître et Grandir website, there were differences in the reported use and benefits. These findings can be explained by the literature on information seeking behavior (Table 3), specifically Bates's integrated model of information seeking [40], in which, there are 2 forms of information seeking: directed, through searching and monitoring when there is a known information need, and undirected, through browsing and being unaware when the information need is unknown.

Table 3. Applying of the integrated model of information seeking [40] to this study's context.

\begin{tabular}{lll}
\hline Form & Naître et Grandir website & Naître et Grandir newsletter \\
\hline $\begin{array}{l}\text { Information need } \\
\text { Information seeking mode }\end{array}$ & Known & Unknown \\
\hline
\end{tabular}

In our study, respondents arrived on the website through directed and active searching that was likely triggered by a known information need such as an existing health problem. The entourage members responding through the website were also aware of the information need by the parents, either because it was stated explicitly by the parents or understood implicitly through social interactions. The entourage members in this context may have closer social ties and may be involved in the decision making, either directly or indirectly, by providing social support. The entourage in this group were thus more likely to report that the information they found would help them to be less worried, help them handle a problem, and help them decide what to do with someone else. On the other hand, entourage respondents through the newsletter were less likely to have a known information need and would have clicked on one of the relevant articles out of interest or curiosity (undirected and passive information seeking). This group was more likely to report that the information would help them improve the health or well-being of a child.

\section{Comparison With Prior Work}

We identified the role of known and unknown information needs on the outcomes of proxy information seeking by entourage members, by comparing entourage website and newsletter users. This is the first unique contribution of our study, as most similar studies [14-16,19] have focus on directed consumer health information seeking on the internet triggered by a known information need. Our study also describes these outcomes from the entourage or proxy seeker's perspective. Another study [11], which explored negative outcomes of seeking consumer health information on the internet from the individual's perspective, reported that in situations wherein informational support from the entourage is unsolicited and the individual does not feel that the information is relevant to their situation, interpersonal tensions between both parties may develop.

We explored the phenomenon of proxy consumer health information seeking using an evidence-based web-based consumer health information source that caters to lower health literacy. Thus, common barriers to positive outcomes such as health literacy and misinformation were somewhat removed, and we could describe the outcomes experienced by parents and their entourage in this context. A recent scoping review [41], which explored parents' web-based health information-seeking behaviors to inform vaccination choices for their children, reported significant misinformation on the topic on the internet and suggested parents' digital health literacy may influence their decisions.

Our results are transferable to other contexts. While we do not claim statistical generalizability as the study sample was self-selected, respondents were not limited by demographic criteria and thus represent a diverse sample of parents and their entourage. Moreover, our respondents rated webpages presenting a wide number of health and well-being topics (ie, not focused on any specific illness or condition). A recent systematic review [22], which explored health information seeking on the internet by parents for their children, identified lack of generalizability as the most frequently mentioned limitation of the studies included in the review. In fact, an agenda item for future research studies was the need for studies with generalizable samples outside clinical environments with specific populations of children who are ill [22]. While the review [22] explored parent health information seeking on the internet as a form of proxy seeking, their findings do not apply to other types of proxy seeking [22]. In this study, we provided insight into another type of proxy seeking and the reported outcomes.

\section{Limitations}

Our study has 3 main limitations. First, participants were self-selected volunteers who completed one questionnaire at one point of time (a source of selection bias). This likely led to an overestimation of positive outcomes due to social desirability bias [42]. However, this bias will have influenced both parents and the entourage in the same manner and thus did not affect the comparative analysis. Moreover, we cannot assume website users and newsletter users were mutually exclusive. Second, we did not explore variables such as the strength of the social ties between the entourage and the parents and child for whom they were using Naître et Grandir. Other studies [16,43,44] have reported that proxy information seekers are likely to have strong ties with the people they are helping and tend to provide 
other forms of social support such as emotional support. This limitation will be addressed in a future study with entourage members.

\section{Conclusions}

The results will be used to refine and improve the existing conceptual framework on consumer health information outcomes on the internet by filling in the gap on the role of the information need. When information is acquired through active directed seeking by the respondents from the Naître et Grandir website, they were likely to use it and report positive outcomes related to an existing problem. When information is acquired from the weekly newsletter, respondents were more likely to report more general positive outcomes. Regardless of how they accessed information, members of the entourage were likely to discuss it with others. Practical intervention strategies can focus on improving proxy health information seeking on the internet and extend social support networks for people without an effective entourage. Future studies can explore how members of the entourage use the information from Naître et Grandir with others in their social circle.

\section{Acknowledgments}

This study was sponsored by the Canadian Institutes of Health Research through a Doctoral research award (RS) and by Naittre et Grandir (Foundation Lucie \& André Chagnon). We gratefully acknowledge the contributions of Dr Fidelia Ibekwe (with her permission).

\section{Authors' Contributions}

PP, TS, and RG provided supervision. All authors contributed to the study design and review of this manuscript. RES performed the statistical analysis.

\section{Conflicts of Interest}

RG and PP are consultants for Naître et Grandir.

\section{Multimedia Appendix 1}

Information Assessment Method questionnaire.

[DOCX File, 16 KB-Multimedia Appendix 1]

\section{References}

1. Communications monitoring report 2019. Canadian Radio-television and Telecommunications Commission. URL: https:/ /crtc.gc.ca/eng/publications/reports/policymonitoring/2019/cmr1.htm\#a0 [accessed 2021-03-31]

2. The internet and digital technology. Statistics Canada. 2017 Nov 14. URL: https://www150.statcan.gc.ca/n1/pub/11-627-m/ 11-627-m2017032-eng.htm [accessed 2021-04-21]

3. More than $80 \%$ of households in OECD countries have access to high-speed internet. OECD iLibrary. URL: https://www. oecd-ilibrary.org/sites/9870c393-en/index.html?itemId=/content/publication/9870c393-en [accessed 2021-04-10]

4. ICT access and usage by households and individuals. OECD iLibrary. 2017. URL: https://doi.org/10.1787/b9823565-en [accessed 2021-04-27]

5. Canada's internet factbook. Canadian Internet Registration Authority. 2020. URL: https://www.cira.ca/resources/factbook/ canadas-internet-factbook-2020 [accessed 2021-03-31]

6. Amante DJ, Hogan TP, Pagoto SL, English TM, Lapane KL. Access to care and use of the internet to search for health information: results from the US National Health Interview Survey. J Med Internet Res 2015 Apr 29;17(4):e106 [FREE Full text] [doi: 10.2196/jmir.4126] [Medline: 25925943]

7. Prescott J, Mackie L. "You sort of go down a rabbit hole...you're just going to keep on searching": a qualitative study of searching online for pregnancy-related information during pregnancy. J Med Internet Res 2017 Jun 05;19(6):e194 [FREE Full text] [doi: 10.2196/jmir.6302] [Medline: 28583906]

8. Case D, Given L. Information needs, motivations, and use. In: Looking for information: A Survey of Research on Information Seeking, Needs, and Behavior. 4th ed. UK: Emerald Group Publishing; 2016.

9. Moreira L. Health literacy for peoplecentred care: Where do OECD countries stand? OECD iLibrary. 2018. URL: https:/ /www.oecd-ilibrary.org/social-issues-migration-health/health-literacy-for-people-centred-care d8494d3a-en [accessed 2021-04-27]

10. Mullen P. Information and emotion: the emergent affective paradigm in information behavior research and theory. Libr Manag 2008 Oct 24;29(8/9):819-820. [doi: 10.1108/01435120810917585]

11. El Sherif R, Pluye P, Thoër C, Rodriguez C. Reducing negative outcomes of online consumer health information: qualitative interpretive study with clinicians, librarians, and consumers. J Med Internet Res 2018 May 04;20(5):e169 [FREE Full text] [doi: 10.2196/jmir.9326] [Medline: 29728350]

12. How's life? measuring well-being. OECD iLibrary. 2020. URL: https://www.oecd-ilibrary.org/content/publication/ 9870c393-en [accessed 2021-03-21] 
13. Chen W. The implications of social capital for the digital divides in America. Inf Soc 2013 Jan;29(1):13-25. [doi: 10.1080/01972243.2012.739265]

14. Reifegerste D, Bachl M, Baumann E. Surrogate health information seeking in Europe: influence of source type and social network variables. Int J Med Inform 2017 Jul;103:7-14. [doi: 10.1016/j.ijmedinf.2017.04.006] [Medline: 28551004]

15. Cutrona SL, Mazor KM, Vieux SN, Luger TM, Volkman JE, Finney Rutten LJ. Health information-seeking on behalf of others: characteristics of "surrogate seekers". J Cancer Educ 2015 Mar 4;30(1):12-19 [FREE Full text] [doi: 10.1007/s13187-014-0701-3] [Medline: 24989816]

16. Selwyn N, Johnson N, Nemorin S, Knight E. In: Clark N, editor. Going online on behalf of others: an investigation of 'proxy' internet consumers. Sydney, Australia: Australian Communications Consumer Action Network; 2016.

17. Agius M, Stangeland H. How does the internet influence the doctor-patient relationship? In: Mucic D, Hilty D, editors. e-Mental Health. Cham: Springer; 2016:251-267.

18. Fox S, Duggan M. Health online. Pew Research Center. 2013. URL: https://www.pewresearch.org/internet/2013/01/15/ health-online-2013/ [accessed 2021-02-25]

19. Cutrona SL, Mazor KM, Agunwamba AA, Valluri S, Wilson PM, Sadasivam RS, et al. Health information brokers in the general population: an analysis of the health information national trends survey 2013-2014. J Med Internet Res 2016 Jun 03;18(6):e123 [FREE Full text] [doi: 10.2196/jmir.5447] [Medline: 27260952]

20. Reifegerste D, Blech S, Dechant P. Understanding information seeking about the health of others: applying the comprehensive model of information seeking to proxy online health information seeking. J Health Commun 2020 Feb 01;25(2):126-135. [doi: 10.1080/10810730.2020.1716280] [Medline: 32009552]

21. Sadasivam RS, Kinney RL, Lemon SC, Shimada SL, Allison JJ, Houston TK. Internet health information seeking is a team sport: analysis of the Pew internet survey. Int J Med Inform 2013 Mar;82(3):193-200. [doi: 10.1016/j.ijmedinf.2012.09.008] [Medline: 23149121]

22. Kubb C, Foran HM. Online health information seeking by parents for their children: systematic review and agenda for further research. J Med Internet Res 2020 Aug 25;22(8):e19985 [FREE Full text] [doi: 10.2196/19985] [Medline: 32840484]

23. Haluza D, Böhm I. Mobile and online health information: exploring digital media use among Austrian parent. Int J Environ Res Public Health 2020 Aug 20;17(17):6053 [FREE Full text] [doi: 10.3390/ijerph17176053] [Medline: 32825293]

24. Pehora C, Gajaria N, Stoute M, Fracassa S, Serebale-O'Sullivan R, Matava CT. Are parents getting it right? a survey of parents? internet use for children's health care information. Interact J Med Res 2015 Jun 22;4(2):e12 [FREE Full text] [doi: 10.2196/ijmr.3790] [Medline: 26099207]

25. Kirchner S, Sakaguchi-Tang D, Michelson R, Munson S, Kientz J. "This just felt to me like the right thing to do?" decision-making experiences of parents of young children. 2020 Presented at: ACM Designing Interactive Systems Conference; July 6-10; Eindhoven, the Netherlands. [doi: 10.1145/3357236.3395466]

26. Mieux connaître la parentalité au Québec. Institut de la Statistique du Québec. URL: https://statistique.quebec.ca/en/fichier/ mieux-connaitre-la-parentalite-au-quebec-un-portrait-a-partir-de-enquete-quebecoise-sur-lexperience-des-parents-denfants-de-0-a-5-ans-2015. pdf [accessed 2022-02-09]

27. Abrahamson JA, Fisher KE, Turner AG, Durrance JC, Turner TC. Lay information mediary behavior uncovered: exploring how nonprofessionals seek health information for themselves and others online. J Med Libr Assoc 2008 Oct;96(4):310-323 [FREE Full text] [doi: 10.3163/1536-5050.96.4.006] [Medline: 18974809]

28. Pluye P, El Sherif R, Gonzalez-Reyes A, Turcotte E, Schuster T, Bartlett G, et al. Outcomes of equity-oriented, web-based parenting information in mothers of low socioeconomic status compared to other mothers: participatory mixed methods study. J Med Internet Res 2020 Nov 10;22(11):e22440 [FREE Full text] [doi: 10.2196/22440] [Medline: 33170125]

29. von Elm E, Altman DG, Egger M, Pocock SJ, Gøtzsche PC, Vandenbroucke JP, STROBE Initiative. The Strengthening the Reporting of Observational Studies in Epidemiology (STROBE) statement: guidelines for reporting observational studies. Ann Intern Med 2007 Oct 16;147(8):573-577 [FREE Full text] [doi: 10.7326/0003-4819-147-8-200710160-00010] [Medline: $\underline{17938396}$ ]

30. Pluye P, El Sherif R, Granikov V, Hong QN, Vedel I, Galvao MCB, et al. Health outcomes of online consumer health information: a systematic mixed studies review with framework synthesis. J Assoc Inf Sci Technol 2019 Jul 30;70(7):643-659 [FREE Full text] [doi: 10.1002/asi.24178] [Medline: $\underline{31423458]}$

31. Derr RL. A conceptual analysis of information need. Inf Proc Manag 1983 Jan;19(5):273-278. [doi: 10.1016/0306-4573(83)90001-8]

32. Wilson TD. Human information behavior. Inf Sci 2000;3:049-056. [doi: 10.28945/576]

33. Connelly R, Turner T, editors. Health Literacy and Child Health Outcomes: Promoting Effective Health Communication Strategies to Improve Quality of Care. USA: Springer Briefs in Public Health; 2017.

34. Sherif R, Roy P, Tang DL, Doray G, Dubois M, Bush P, et al. The value of user feedback: parent's comments to online health and well - being information providers. Proc Assoc Info Sci Tech 2017 Oct 24;54(1):662-663. [doi: 10.1002/pra2.2017.14505401107]

35. Granikov V, Grad R, El Sherif R, Shulha M, Chaput G, Doray G, et al. The information assessment method: over 15 years of research evaluating the value of health information. EFI 2020 Apr 03;36(1):7-18. [doi: 10.3233/efi-190348] 
36. Pluye P, Granikov V, Bartlett G, Grad RM, Tang DL, Johnson-Lafleur J, et al. Development and content validation of the information assessment method for patients and consumers. JMIR Res Protoc 2014 Feb 18;3(1):e7 [FREE Full text] [doi: 10.2196/resprot.2908] [Medline: 24550180]

37. Bujold M, El Sherif R, Bush P, Johnson-Lafleur J, Doray G, Pluye P. Ecological content validation of the information assessment method for parents (IAM-parent): a mixed methods study. Eval Program Plann 2018 Feb;66:79-88 [FREE Full text] [doi: 10.1016/j.evalprogplan.2017.09.011] [Medline: 29053984]

38. Newcombe RG. Interval estimation for the difference between independent proportions: comparison of eleven methods. Stat Med 1998 Apr 30;17(8):873-890. [doi: 10.1002/(sici)1097-0258(19980430)17:8<873::aid-sim779>3.0.co;2-i] [Medline: 9595617]

39. Lowry R. The confidence interval for the difference between two independent proportions web calculator. VassarStats. 2019. URL: http://vassarstats.net/prop2 ind.html [accessed 2021-05-07]

40. Bates M. Toward an integrated model of information seeking and searching. 2002 Presented at: Fourth International Conference on Information Needs, Seeking and Use in Different Contexts; September 11; Lisbon, Portugal.

41. Ashfield S, Donelle L. Parental online information access and childhood vaccination decisions in North America: scoping review. J Med Internet Res 2020 Oct 13;22(10):e20002 [FREE Full text] [doi: 10.2196/20002] [Medline: 33048055]

42. Nederhof AJ. Methods of coping with social desirability bias: a review. Eur J Soc Psychol 1985 Jul;15(3):263-280. [doi: 10.1002/ejsp.2420150303]

43. Criss S, Woo Baidal JA, Goldman RE, Perkins M, Cunningham C, Taveras EM. The role of health information sources in decision-making among Hispanic mothers during their children's first 1000 days of life. Matern Child Health J 2015 Nov 30;19(11):2536-2543 [FREE Full text] [doi: 10.1007/s10995-015-1774-2] [Medline: 26122256]

44. Dolničar V, Hrast M, Vehovar V, Petrovčič A. Digital inequality and intergenerational solidarity: the role of social support in proxy internet use. AoIR Selected Papers of Internet Research 2013:IR14 [FREE Full text]

\section{Abbreviations \\ OECD: Organization for Economic Cooperation and Development}

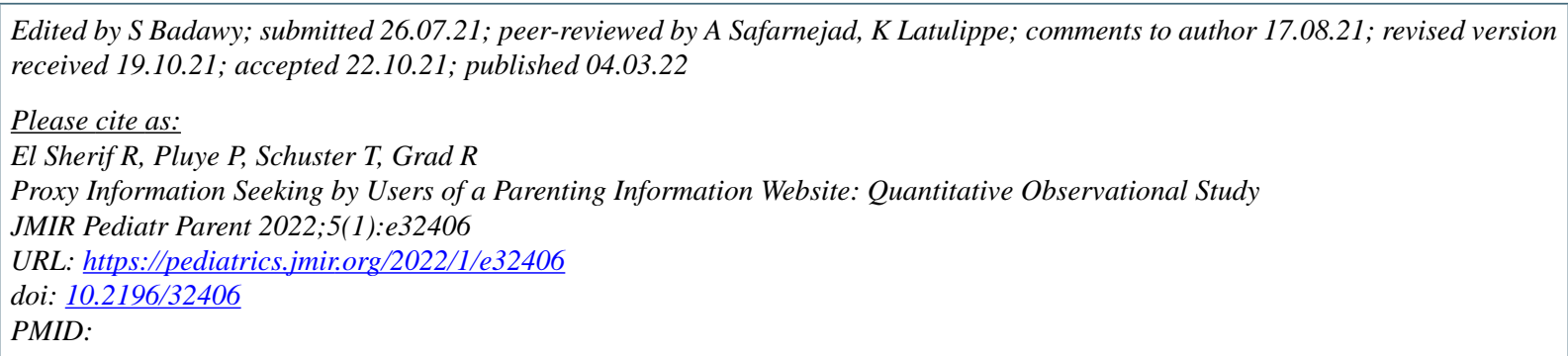

CReem El Sherif, Pierre Pluye, Tibor Schuster, Roland Grad. Originally published in JMIR Pediatrics and Parenting (https://pediatrics.jmir.org), 04.03.2022. This is an open-access article distributed under the terms of the Creative Commons Attribution License (https://creativecommons.org/licenses/by/4.0/), which permits unrestricted use, distribution, and reproduction in any medium, provided the original work, first published in JMIR Pediatrics and Parenting, is properly cited. The complete bibliographic information, a link to the original publication on https://pediatrics.jmir.org, as well as this copyright and license information must be included. 